\title{
Cement boards reinforced with wood sawdust: an option for sustainable construction
}

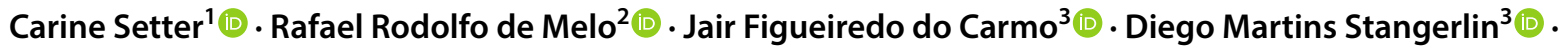 \\ Alexandre Santos Pimenta ${ }^{4}$ (i)
}

Received: 7 April 2020 / Accepted: 27 August 2020 / Published online: 5 September 2020

(c) Springer Nature Switzerland AG 2020

\begin{abstract}
Ochroma pyramidale is a fast-growing forest species with low-density wood. The present study had the goal to assess the effect of extractive removal on the performance of the species for producing wood-cement boards (WCB). Wood particles were submitted to three types of treatment for extractives removal: cold water, hot water and sodium hydroxide $(\mathrm{NaOH})$. An entirely randomized design with four treatments was established, respectively, T1 - control treatment, T2-cold water, $\mathrm{T} 3$ - hot water and $\mathrm{T} 4-\mathrm{NaOH}$, with 4 replicates (boards) per experimental treatment, to assess the effect of extractives removal on the boards' physical and mechanical properties. Wood/cement ratio $=1: 5$, water/cement ratio $=1: 2$ and $4 \% \mathrm{CaCl}_{2}$ as additive based on dry mass of cement were used. The following WCB properties were evaluated: density, compaction ratio; water absorption and thickness swelling after 2, 24 and $72 \mathrm{~h}$ of water immersion; and mechanical strength during static bending (moduli of elasticity and rupture). The results showed there was no need for wood particle treatment, since no improvement of the boards' physical-mechanical properties was achieved by previous application of cold or hot water or $\mathrm{NaOH}$ on the particles. Water absorption and thickness swelling were lower than the levels reported in the literature and minimum values specified by WCB factories. Despite having weaker mechanical properties than those required for structural uses, wood from Ochroma pyramidale can be employed in the production of boards designed for use in moist environments but not having structural importance, such as for partitions, walls, tile flooring and exterior siding.
\end{abstract}

$\triangle$ Alexandre Santos Pimenta, aspimenta@ufrnet.br; Carine Setter, carine_cah@hotmail.com; Rafael Rodolfo de Melo, rafael.melo@ufersa.edu.br; Jair Figueiredo do Carmo, carmo.jair@gmail.com; Diego Martins Stangerlin, stangerlin@ufmt.br| ${ }^{1}$ Graduate Wood Science and Technology Program, Federal University of Lavras - UFLA, Aquenta Sol, Lavras, MG CEP 37200-900, Brazil. ${ }^{2}$ Agriculture Sciences Center, Federal University of Semiarid - UFERSA, Av. Francisco Mota, 572 - Bairro Costa e Silva, Mossoró, RN CEP 59.625-900, Brazil. ${ }^{3}$ Agricultural and Environmental Sciences Institute, Federal University of Mato Grosso - UFMT, Av. Alexandre Ferronato, 1200 Bairro Setor Industrial, Sinop, MT CEP 78557-267, Brazil. ${ }^{4}$ Agricultural Sciences Academic Unit, Graduate Forest Sciences Program PPGCFL, Forest, Bioenergy and Environment Research Group, Federal University of Rio Grande do Norte - UFRN, RN 160, km 03, Macaíba, RN CEP 59.280-000, Brazil. 


\section{Graphic abstract}

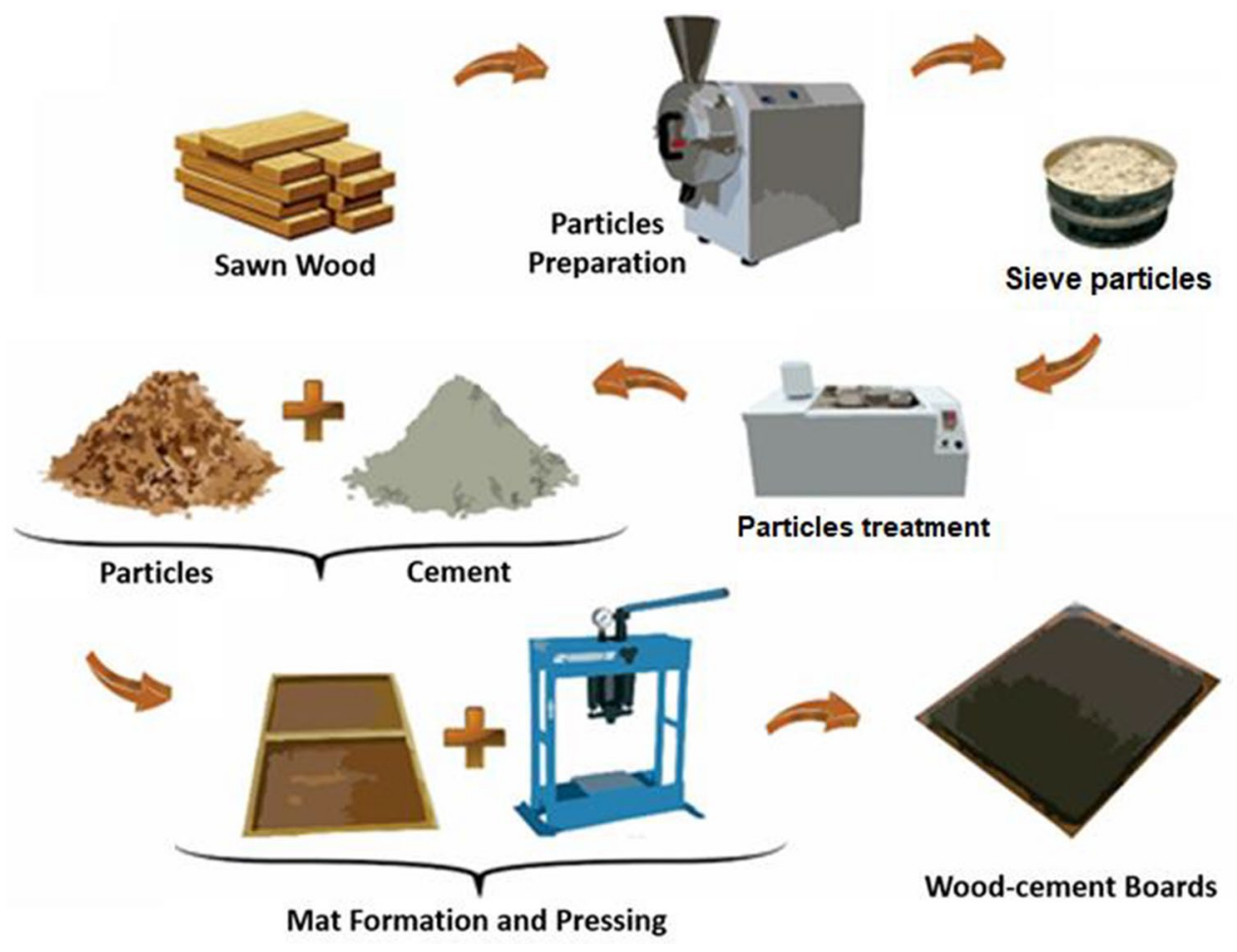

Keywords Alternative construction materials · Sustainable materials $\cdot$ Wood-cement boards

\section{Introduction}

Brazil's forest-based industry has significant importance to the national economy, with a share of $6.1 \%$ of gross domestic product, or US\$ 73.8 billion. This sector produces a wide range of products, such as solid wood, sawn lumber, pulp and paper, charcoal, plywood, wood boards and furniture. Upstream and downstream from these industries, several other industrial segments are associated, such as chemicals, paints and varnishes, and metalworking, among others. Wood products in Brazil are steadily gaining space, even during the economic crisis of the present decade $[1,11]$.

The increasing demand for wood products has raised concern about the future of supply. Therefore, the forest sector has been searching for alternative wood species with potential to replace or complement the provision of woody raw material to industries besides the species traditionally employed [11]. Forestation with new species is by far the best alternative to remediate deforestation of natural areas such the Amazon and at the same time keep wood product industries properly supplied. Among the native species with potential for planting in either commercial pure or intercropped stands, Ochroma pyramidale is one of the potential options. The genus Ochroma provides the lowest density (range of $100-200 \mathrm{~kg} \mathrm{~m}^{3}$ ) types of wood, which is widely used for mockups, toys and model planes. In Brazil, has the largest forested area with this specie [37]. The species is employed for the recovery of degraded areas due to its high tolerance to luminosity and fast growth, besides providing a soft wood with easy workability [38].

The use of low-density wood for board manufacturing results in products with superior mechanical quality than high-density wood. Thus, low density is one of the factors influencing the rating of a wood species for board production [13, 28, 34]. Mineral boards are composed basically of a mixture of wood, a mineral agglutinant like cement, water and chemical additives. The boards are then hardened through exothermal reactions that result from cement hydration in the presence of water. The high 
acceptability of wood-cement boards (WCB) is due to their low cost, high mechanical strength, low susceptibility to fungi and xylophagous insect attack, good resistance to moisture, good thermal and acoustic isolation properties, easy workability and partially non-combustible nature [26]. In addition, compared to conventional materials used in civil construction, WCBs, as they contain biodegradable particles, can be considered sustainable composites, since the wood come from certified forests subjected to sustainable management [39]. By using them, the addition of petroleum-based fibers is reduced, the use of asbestos, cement consumption is reduced and agribusiness and timber residues are used $[2,15,22,35]$.

The main limitation to WCB production is the chemical composition of wood $[12,23]$. Depending on the type of extractives present in the raw material, some incompatibility between wood species and the mineral binder can occur. In general, the wood species used for WCB production are conifers, since they usually are more chemically compatible with the cement because they do not have substances that disturb its hardening $[13,21]$. In contrast, tropical species present the highest levels of incompatibility to the normal hardening of cement, due to both to the quality and concentration of extractives. In studies carried out by Castro et al. [13], extractive amounts over $15 \%$ were determined for tropical wood species. However, as reported by $\mathrm{Na}$ et al. [29], the non-compatibility of the cement with wood is not only regarded as extractives but also for their chemical nature. In general, the substances able to inhibit the cement curing process can be divided into two types, the carbohydrates, and the phenolic compounds. Besides chemical composition, also $\mathrm{pH}$ and hydrophobicity of these components are responsible for the inhibition ability. Thus, to enable the use of species with high amounts of extractives, it is necessary to treat the particles to remove incompatible chemicals. Among the treatments most widely employed for the removal of extractives, immersion in cold water for $24 \mathrm{~h}$, immersion in hot water for $6 \mathrm{~h}$ and immersion of particles in sodium hydroxide solution at concentration of $1 \mathrm{wt} \%$ stand out $[30,33]$.

In the Brazilian market, the forest sector represents $10 \%$ of the agribusiness responding for $4.5 \%$ of all goods exported by Brazil. The silviculture is one of the most important and productive in the world because of the high quality of the forest stands and the prevalent edaphoclimatic conditions in the country. These factors significantly make competitive the Brazilian forest products in the world market. In the domestic market, the sector represents $10 \%$ of the agribusiness responding for $4.5 \%$ of all goods exported by Brazil [31].
The Ochroma pyramidale is a wood species native from Amazon and when compared to other regional species has remarkable growth rate and biomass yield per hectare at the time of harvesting. The fast growth (higher than $20 \mathrm{~m}^{3} \mathrm{ha}^{-1}$ year ${ }^{-1}$ ) has made countless farmers to invest in commercial plantations with this species in the last 10 years [37]. However, its low basic density limits the employability of the wood for most traditional uses which has caused massive waste wood and even the abandonment of some plantations by the farmers. Species from Ochroma genus are referred as having the lowest known wood densities, varying in the range of $100-200 \mathrm{~kg} \mathrm{~m}^{-3}$ [12].

Nowadays, the use of Ochroma pyramidale, for instance, is concentrated in the making of helixes for wind power generation towers and small aircrafts, aeromodelling, small wooden objects and craftsmanship. As function of the specificity of these cited uses and their limited demand, only a relatively part of the overall planted area with Ochroma pyramidale trees is effectively being properly destined. So, the present study objectives to bring technical subsidies to using the wood species in employments able to consume larger volumes of raw material per year. Such new uses if technically feasible would lead to a correct and better industrial destination for the wood along with economic return capable of bringing back to business the farmers who abandoned their plantations and even stimulate new investments in the sector due to the noteworthy fast growth of this species. Besides, at this point, adopting a native wood for panels production is relevant, because the introduction of non-native species is not considered a proper solution in many countries, notwithstanding they have remarkable productivity since the unknown environmental impact that can result from their employment can is be determined.

The novelty of this research work is to bring forward an alternative use for the Ochroma pyramidale which is the production of wood-cement boards having its wood as source of fibrous material. So far, no previous research work has assessed this sort of alternative use. The present work aimed to produce and assess the physical-chemical performance of WCB made with wood particles from Ochroma pyramidale submitted to different types of chemical treatment.

\section{Materials and methods}

\subsection{Materials used}

The materials used in the experiment for cement wood board production included particles of Ochroma pyramidale, high-performance Portland cement, water and $\mathrm{CaCl}_{2}$ 
as curing accelerator. Six trees of the species were selected randomly and harvested from a 6-year-old stand. Three trees were collected in the municipality of Nova Guarita (geographical coordinates of $10^{\circ} 18^{\prime} 47^{\prime \prime} \mathrm{S}$ and longitude $\left.55^{\circ} 24^{\prime} 30^{\prime \prime} \mathrm{W}\right)$, and three others in Sinop ( $11^{\circ} 51^{\prime} 51^{\prime \prime} \mathrm{S}$ and $55^{\circ} 30^{\prime} 09^{\prime \prime}$ W), both located in Mato Grosso State, Brazil.

\subsection{Wood density determination}

After cutting off the crown from each trunk, five 3-cm thick disks were obtained, respectively at $0,25,50,75$ and $100 \%$ of the resulting commercial log length, following the procedures described by Hsing et al. [19] and Benin et al. [9]. Four-cm diameter wood disks were collected from each sampling point along the log length and cut into wedges for determination of basic density according the procedures from the ASTM D 2395 [5]. After sampling, logs were taken to a sawmill and cut into boards for further particle production.

\subsection{Chemical characterization of the wood}

Chemical analyses were carried out in triplicate using sawdust from wood chips. The sawdust was previously classified by sieving and the granulometry in the range from 0.25 to $0.42 \mathrm{~mm}$ was selected. The total extractives, acid-soluble and insoluble lignin (Klason) and ash contents were determined by following the procedures described in the standards ABNT NBR 14853, 7989 and 13999 [6, 7, 8], respectively.

\subsection{Cement and particle preparation}

Portland cement CP V-ARI was used as binder. This cement was chosen because it is able to reach higher strength in shorter periods compared to the commonest cements [3]. To accelerate both curing and hardening of cement, calcium chloride $\left(\mathrm{CaCl}_{2}\right)$ was selected due to its low cost and high efficiency in promoting hydration of sodium silicates, especially $\mathrm{Ca}_{2} \mathrm{SiO}_{4}$. Logs were sawn into boards measuring $10 \mathrm{~cm}$ width $\times 2.5 \mathrm{~cm}$ thickness and $1.30 \mathrm{~m}$ length. These boards were dried and processed using an electric thickness planer to produce the wood shavings. The shavings were sieved and the fraction with granulometry between 0.09 and $0.19 \mathrm{~mm}$ was collected for further use in woodcement board production.

\subsection{Particle treatment}

Wood particles were submitted to different treatments to evaluate if there was a negative effect of extractives on WCB production via inhibition of cement curing and hardening. Thus, the treatments had the basic goal of removing extractives from wood particles to possibly accelerate the curing and hardening of cement and consequently improve the mechanical strength of boards. The experimental design consisted of one reference and three types of treatment, as follows: untreated particles (T1), cold water (T2), hot water (T3) and sodium hydroxide (T4).

In $\mathrm{T} 1$, the particles were used in the natural state in which they were obtained. Treatment 2 consisted of soaking the particles in cold water $\left(25^{\circ} \mathrm{C}\right)$ until complete saturation for $24 \mathrm{~h}$ under periodic agitation. After soaking, the water was drained and the particles were washed in running water until it became colorless, which indicated the all cold-water-extractable components were removed. Treatment 3 consisted of immersion of particles in hot water $\left(80^{\circ} \mathrm{C}\right)$ for $2 \mathrm{~h}$, to obtain maximum removal of extractives. In this treatment, after soaking the particles, the water was drained and they were washed until thorough removal of solubilized extractives. Treatment 4 consisted of the immersion of particles in $1 \mathrm{wt} \%$ sodium hydroxide solution for $2 \mathrm{~h}$ with periodic agitation, followed by draining the solution and washing the particles remove solubilized extractives and also to eliminate as much as possible all $\mathrm{NaOH}$ residues.

After all treatments, the particles were dried at ambient temperature reaching moisture content of $12 \%$ and then were sieved again to select particles in the granulometry range from 0.09 to $0.19 \mathrm{~mm}$, with the material under $0.19 \mathrm{~mm}$ being discarding as waste. For each experimental treatment, 4 boards were produced and analyzed.

\subsection{Wood-cement board production}

For WCB production, the amounts of each component by mass were defined as water/cement ratio $=1: 2$, wood/ cement ratio $=1: 5$ and $4 \% \mathrm{CaCl}_{2}$ based on dry mass of cement. All calculations of component ratios were made with the goal of producing boards with density equal to $1100 \mathrm{~kg} \mathrm{~m}^{3}$ in the nominal dimensions of $31.0 \mathrm{~cm}$ width $\times 36 \mathrm{~cm}$ length $\times 1.5 \mathrm{~cm}$ thickness. After weighing, the components were placed step by step in plastic containers and mixed until complete homogenization, as described below. For all treatments, first the $\mathrm{CaCl}_{2}$ was diluted in water. After this, wood particles and cement were mixed and during the process, water containing $\mathrm{CaCl}_{2}$ was sprayed until mixing was concluded. Four panels were produced in each experimental treatment.

Then the resulting paste was distributed in a mold slightly greased with mineral oil to make removal of the boards after hardening easier. After the paste was distributed in the mold, it was pressed with a manual hydraulic press to define the boards' final thickness. Each prepressed mat was fastened with clamps and kept under a load of 5 tons at room temperature for $24 \mathrm{~h}$. After this 
time, the clamps were removed and the boards were kept in a conditioning chamber at $20 \pm 2{ }^{\circ} \mathrm{C}$ and $65 \pm 5 \%$ relative humidity for 28 days until complete curing of cement and drying of boards. After this period, the boards were trimmed and test specimens were cut for evaluation of physical and mechanical properties.

\subsection{Physical mechanical properties}

The physical properties evaluated in the experiment were density according procedures described in the standard EN 323 [17] and, water absorption and thickness swelling by following the procedures from the standard ASTM D-1037 [4]. Density was measured by the ratio between initial volume and mass of test specimens (stereometric method) by using a pachymeter and precision scale, respectively. Compaction ratio was calculated by dividing the board density by the wood density.

For water absorption and thickness swelling determination, the test specimens were immersed in cold water $\left(25^{\circ} \mathrm{C}\right)$ and soaked for 2,24 and $72 \mathrm{~h}$, with measurement of both weigh and volume after each period. Mechanical properties were strength and rigidity in static bending determined by following the procedures of the standard EN 310 [16]. The static bending test was carried out to obtain both moduli of elasticity and rupture (MOE and MOR) by using a universal testing machine equipped with a $30 \mathrm{KN}$ compression/tension load cell.

\subsection{Experimental data analysis}

Experimental data were statistically assessed in an entirely randomized design with 4 treatments and 4 replicates (boards). The results of all physical-mechanical tests were submitted to analysis of variance and when significant

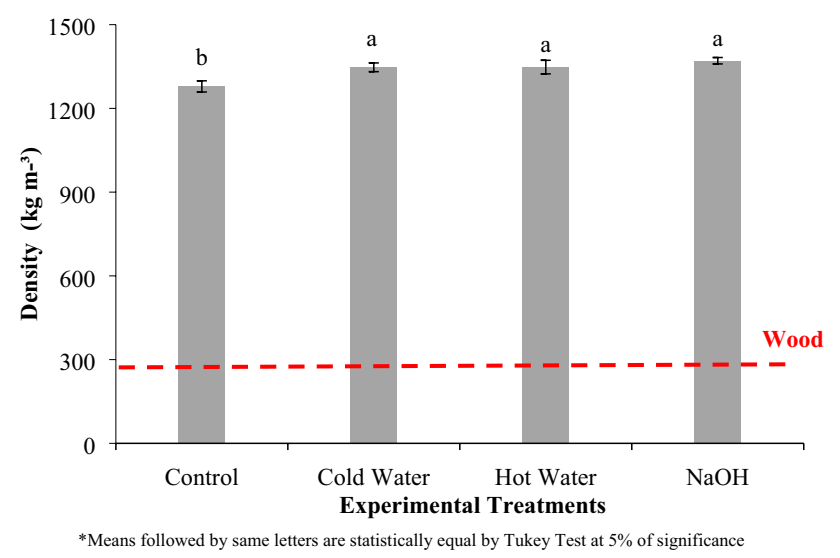

Fig. 1 Mean values and statistical comparison of density of woodcement boards produced with wood particles submitted to different types of treatment

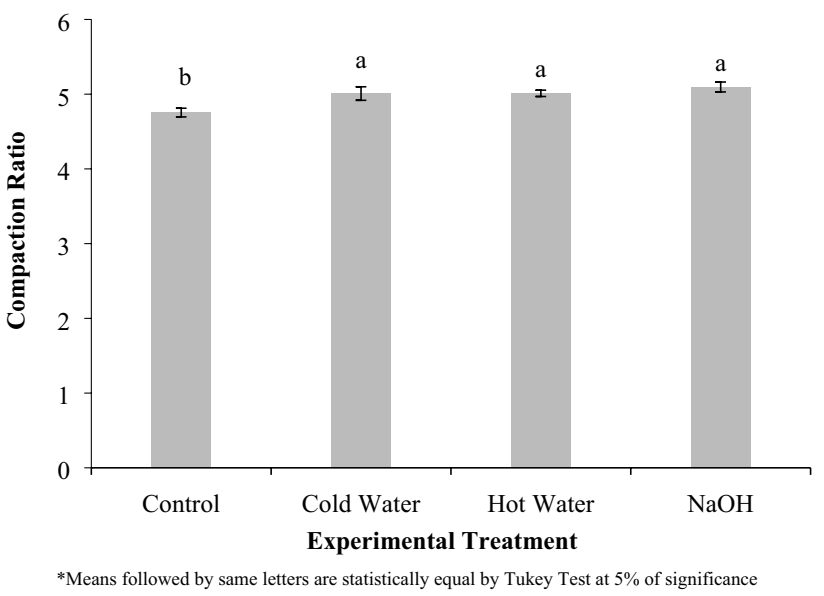

Fig. 2 Mean values and statistical comparison of compaction ratios of wood-cement boards produced with wood particles submitted to different types of treatment

statistical difference between treatments was detected, their means were compared by the Tukey test at $5 \%$ significance ( $95 \%$ probability).

\section{Results and discussion}

\subsection{Physical properties}

The results obtained for wood density from the Ochroma pyramidale trees which was $270 \mathrm{~kg} \mathrm{~m}^{-3}$, varied in the range of $250-290 \mathrm{~kg} \mathrm{~m}^{3}$. For WCB mean values of density varied in the range of $1128-1370 \mathrm{~kg} \mathrm{~m}^{3}$. The density determined for the control treatment was the only value which differed statistically from the other experimental treatments, as shown in Fig. 1.

Knowledge of the basic density is important since the amount of wood in the board and its final density are influenced by this parameter $[13,25,34]$. High compaction ratios usually are related to high mechanical strength, but they also can cause drawbacks to other properties, such as hygroscopic swelling of wood in function of hightension rates, originated during the pressing step [21]. In the present experiment, the high compaction ratio might be related to the cement/wood ratio of 5:1 adopted, in line with the result of Macêdo et al. [26], who reported that higher cement proportions are associated with greater density and compaction ratio.

Figure 2 shows the compaction ratio of the woodcement boards. This parameter varied from 4.72 to 5.08 . The control treatment showed the lowest value for this parameter. This was also the only one among those analyzed that differed statistically. 


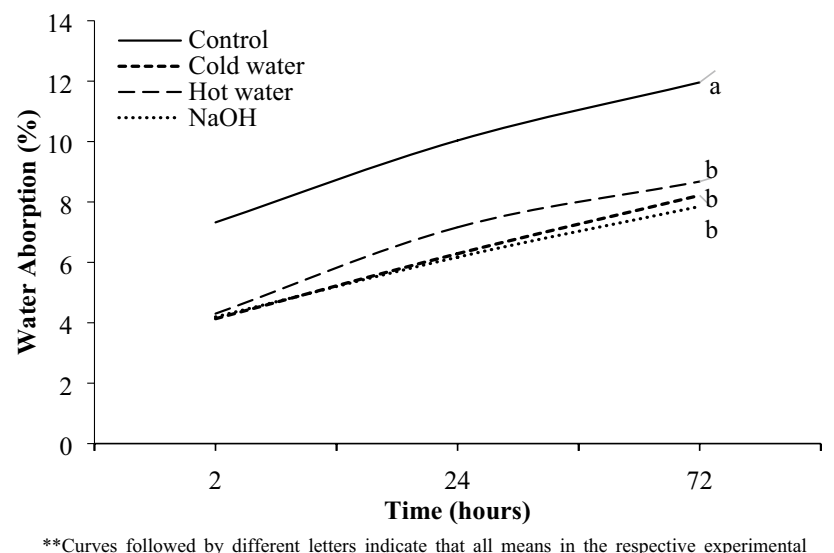

thenterent indicate that means in the

Fig. 3 Water absorption of wood-cement boards after 2, 24 and $72 \mathrm{~h}$ of immersion as a function of wood particle treatment

As shown in Fig. 3, the values found for water absorption indicated that boards made with wood particles with no prior treatment (T1) presented the highest absorption percentage during the immersion period, statistically differing from the others. For the evaluation after $24 \mathrm{~h}$ of immersion, all experimental treatments ( $T 2, \mathrm{~T} 3$ and $\mathrm{T} 4)$ were statistically different from the control treatment (7.32\%), but they were no significant difference between each other, with mean values of $6.29,7.16$ and $6.17 \%$ for cold water, hot water and sodium hydroxide treatments, respectively. For 24 and $72 \mathrm{~h}, \mathrm{T1}$ presented water absorption of 10.04 and $11.96 \%$, respectively. For both periods, T2 had values of 6.29 and $8.22 \%, \mathrm{~T} 3$ of 7.16 and $8.68 \%$ and, T4 of 6.17 and $7.84 \%$. At each immersion time and among $\mathrm{T} 2, \mathrm{~T} 3$ and $\mathrm{T} 4$ there was no statistical difference of their mean values.

The values found in the present experiment for water absorption were lower than those reported by other authors, for instance Pomarico [32], who worked with particles of eucalyptus clone wood and reported mean values from 2.92 to $12.50 \%$ and 6.12 to $16.06 \%$ for water absorption after 2 and $24 \mathrm{~h}$ of immersion. In an experiment assessing the influence of wood from four species of eucalyptus on the physical properties of wood-cement boards, Latorraca et al. [25] observed mean values from 12.90 to $18.74 \%$ for the 2 -h water immersion test and values from 15.69 to $22.22 \%$ for the 24 -h immersion test. Usually the water absorption is related directly with basic density and porosity of the lignocellulosic material used in the wood-cement board. As the proportion of woody material increases, the board density tends to decrease and the water absorption increase concomitantly, which significantly affects the boards' properties. Most likely, the higher values of water absorption observed by the authors cited above are related to differences in the proportion of cement and woody material used in comparison to our experiment.

In this work, a correlation between board density and water absorption was observed, since for boards from the control treatment had lower density and higher water absorption. The correlation of the compaction with water absorption for wood-cement boards, presenting experimental results demonstrating that higher compaction ratio values were associated with lower water absorption. This decrease in water absorption is probably due to the decrease of porosity among particles promoted by higher compaction ratios, which either hinders or blocks absorption by the lignocellulosic particles [28].

Also, the granulometry of particles affects water absorption, so boards with higher amounts of fiber and fine particles tend to have higher absorption because of their higher specific area [13]. According to Latorraca et al. [25] and Iwakiri et al. [21] as well, the variation in the granulometry of particles influences the water absorption. Thus, to prevent this type of influence, the particles in all the experimental treatments tested in the present work had the same granulometry. This way, the statistical differences of properties can be attributed to either to board density or compaction ratio. In this sense, as cited previously, boards from the control treatment had lower density and higher water absorption in comparison with the other treatments. The company Cetris [14], a manufacturer of wood-cement boards, demands a maximum water absorption value of $32 \%$, so the boards produced in this experiment are in compliance with that specification.

As shown in Fig. 4, the thickness swelling varied from 0.16 to $0.47 \%$, with no statistical difference among the experimental treatments. Despite this absence of differences, the results found for thickness swelling are lower than those reported in the literature.

Despite this absence of differences, the results found for thickness swelling are lower than those reported in the literature. For instance, Macêdo et al. [26] assessed woodcement boards produced with sawmill wastes from tropical species and found values for TS of $0.52 \%$ for Hymenea courbaril, $0.60 \%$ for Vochisia maxima, $0.72 \%$ for Cedrela odorata and $0.85 \%$ for a mixture of wastes from these species. For wood-cement boards produced with particles of Toona ciliata var. australis, Sá et al. [36] determined 2 and 24-h thickness swelling of 0.35 and $0.97 \%$, respectively.

Also, Iwakiri et al. [20], working with two species of tropical hardwoods, found values for 24 -h thickness swelling varying from 1.38 to $1.95 \%$ for Schizolobium amazonicum and from 0.35 to $0.97 \%$ for Cecropia hololeuca. The average thickness swelling values determined here were lower than those established by the manufacturer Cetris [14], which sets maximum values of $0.80 \%$ after $2 \mathrm{~h}$ of water 


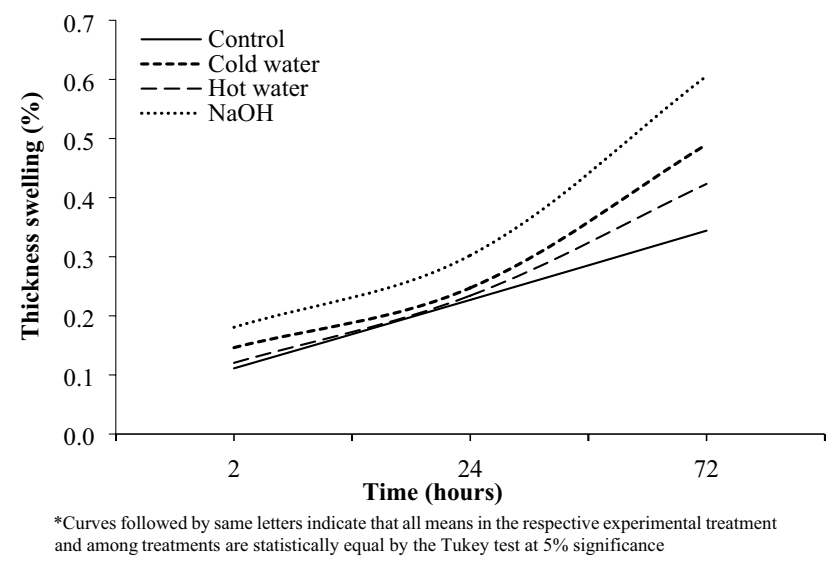

Fig. 4 Thickness swelling of wood-cement boards after 2, 24 and $72 \mathrm{~h}$ as a function of wood particle treatment

Table 1 Chemical characterization of Ochroma pyramidale wood

\begin{tabular}{lc}
\hline Chemical content & $\begin{array}{l}\text { Average } \pm \text { Standard } \\
\text { deviation }\end{array}$ \\
\hline Holocellulose (\%) & $71.57 \pm 0.33$ \\
Lignin (\%) & $22.65 \pm 0.20$ \\
Extractives (\%) & $5.78 \pm 0.35$ \\
Ash (\%) & $1.03 \pm 0.28$ \\
\hline
\end{tabular}

immersion and from 1.2 to $1.8 \%$ after $24 \mathrm{~h}$. Therefore, the boards produced in the present work are adequate of use in moist environments due to their high dimensional stability, even after long water immersion of $72 \mathrm{~h}$.

\subsection{Chemical properties of the Ochroma pyramidale wood}

The chemical properties of the Ochroma pyramidale wood are shown in Table 1. The chemical characterization is fundamental to assess the feasibility of the use of a given wood in the production of wood-cement panels mainly because of the extractives content. In the present case, this parameter is low when compared to the most tropical species. The main effect of a high extractives content might be the slowing in the curing of the cement as previously pointed out in the introduction by considering the results achieved by Castro et al. [13] and the comments of $\mathrm{Na}$ et al. [29] (Fig. 5).

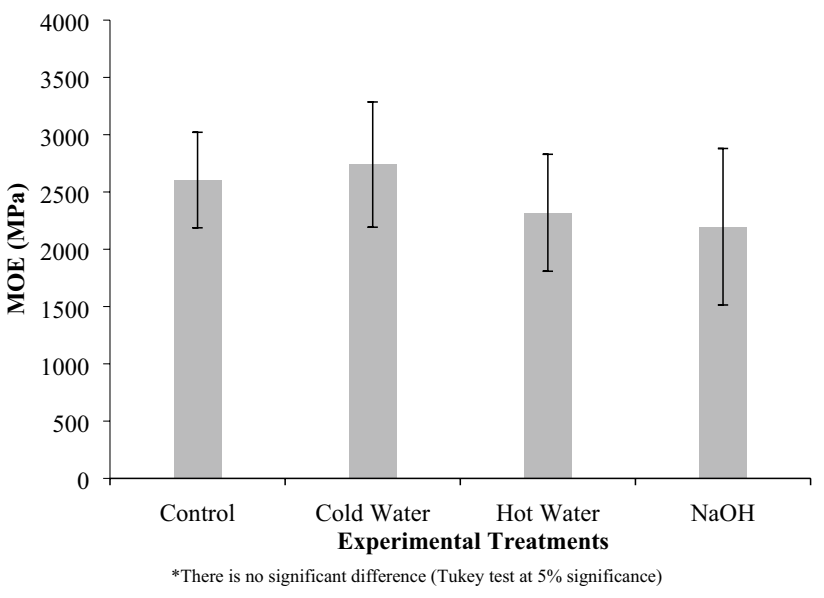

Fig. 5 Mean values and statistical comparison of modulus of elasticity (MOE) from wood-cement boards produced with wood particles submitted to different types of treatment

\subsection{Mechanical properties}

As shown in Fig. 6, there was no statistical difference among boards manufactured with pre-processed particles according the conditions of each experimental treatment.

Mean values of modulus of rupture (MOR) for wood boards as a function of the type of wood particle treatment are shown in Fig. 6. There was no effect of the type of treatment on the MOR.

Mean values of modulus of elasticity (MOE) found in this work (from 2197 to $2739 \mathrm{MPa}$ ) are close to those observed by other authors [18, 21]. For example, Iwakiri et al. [21], who worked with particles of Eucalyptus benthamii wood, observed values in the range of 2613-3821 MPa. In contrast, some researchers have found higher values compared to those reported here.

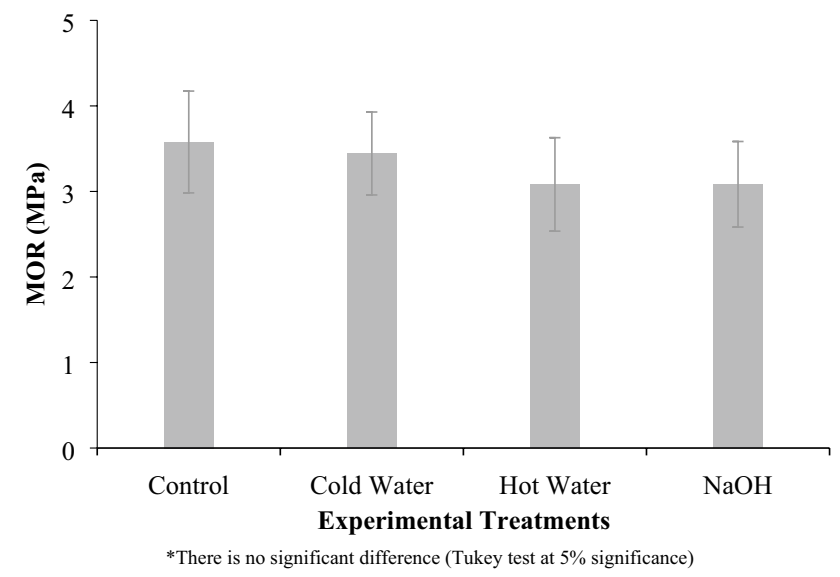

Fig. 6 Mean values and statistical comparison of modulus of rupture (MOR) of wood-cement boards produced with wood particles submitted to different types of treatment 
For instance, Guimarães et al. [18], evaluating the efficiency of using particles from a Eucalyptus grandis $x$ Eucalyptus camaldulensis hybrid, found MOE values between 3578 and $5338 \mathrm{MPa}$. The Bison process [10] establishes a value of $3000 \mathrm{MPa}$ as the minimum for the MOE of woodcement boards. In comparison with this parameter, the boards produced and assessed here were not satisfactory, since no treatment reached that MOE value. Despite this, as mentioned above, the MOE values reported here are in accordance with values found by other researchers.

There was no effect of the type of treatment on the MOR. Once again, the requirement of minimum mechanical strength of 9.0 MPa for the MOR established by the Bison process [10] was not reached, because woodcement boards produced in the present work had MOR in the range of 3.08-3.58 MPa. However, these values are similar to those reported in the literature. For example, Mendes et al. [27] observed average MOR values between 3.49 and $4.41 \mathrm{MPa}$ for boards produced with particles of different Eucalyptus urophylla clones.

Mean values in the range of 2.56-4.00 MPa were determined by Latorraca and Iwakiri [24] in an experiment to assess effects of particle treatment on mechanical performance of wood-cement boards produced with Eucalyptus dunnii wood. The failure of both moduli, respectively, MOE and MOR, to comply with the Bison requirements [10] might be related to the low density of Ochroma pyramidale wood $\left(250-290 \mathrm{~kg} \mathrm{~m}^{-3}\right)$, but this fact alone is not enough to explain the values of MOE and MOR obtained for the wood-cement boards produced in this work, since some of the authors mentioned above also found low values for these properties even though working with wood types with almost twice the density of the wood used here.

However, in some cases, as pointed out by Castro et al. [13], treatment of particles might be counter-productive, by inhibiting the hydration reactions during the cement curing, negatively affecting the boards' mechanical performance. Therefore, according the same authors, for some species previous particle treatments are not necessary. This is an important finding, because in cases like this, a treatment step not only increases the manufacturing cost, it can negatively affect the mechanical performance.

In the present experiment, the treatment of particles to remove extractives did not bring any highly significant improvement of the final quality of boards from both physical and mechanical standpoints. Despite having mechanical properties lower than those required for structural uses, wood from Ochroma pyramidale can be employed for the production of boards designed for moist environments but not having structural importance, such as for partitions, walls, flooring and exterior siding.

\section{Conclusions}

The species Ochroma pyramidale is a good alternative for producing wood-cement boards regarding physical properties, since all values of water absorption and thickness swelling were lower than those reported in the literature and additionally were in compliance with the requirements of manufacturers.

Nevertheless, the boards presented mechanical properties compatible with data from literature but lower than what manufacturers require for commercial products. Another positive characteristic is that there is no need for particle treatment, which reduces the production cost.

Further experiments with Ochroma pyramidale wood for producing wood-cement boards should be carried out considering, for example, variation in granulometry, cement/wood ratio, water/cement ratio and variation in the percentage of additives, with the goal of improving the mechanical properties and qualifying the species for commercial use.

\section{Compliance with ethical standards}

Conflict of interest All authors agree with this submission and declare there is no conflict of interest associated to the article subject or content.

\section{References}

1. Abreu Neto R, de Assis AA, Ballarin AW, Hein PRG (2020) Effect of final temperature on charcoal stiffness and its correlation with wood density and hardness. SN Appl Sci 2(4):1020. https://doi. org/10.1007/s42452-020-2822-0

2. Aditya L, Mahlia TMI, Rismanchi B, Ng HM, Hasan MH, Metselaar HSC, Muraza O, Aditiya HB (2017) A review on insulation materials for energy conservation in buildings. Renew Sustaint Energy Rev 73(1):1352-1365. https://doi.org/10.1016/j.rser.2017.02.034

3. Alberto MM, Mougel E, Zoulalian A (2000) Compatibility if some tropical hardwoods species with Portland cement using isothermal calorimetry. For Prod J 50(9):83-88

4. American Society for Testing and Materials (2012) ASTM D 1037. Standard test methods for evaluating properties of wood-based fiber and particle board materials. Annual Book of ASTM Standards, Philadelphia. https://doi.org/10.1520/D1037-12

5. American Society for Testing and Materials (2017) ASTM D 2395. Standard test methods for density and specific gravity (relative density) of wood and wood-based materials. Annual Book of ASTM Standards, Philadelphia. https://doi.org/10.1520/D2395 $-17$

6. Associação Brasileira de Normas Técnicas (2010) NBR 14853: Madeira - Determinação do material solúvel em etanol-tolueno e em diclorometano. ABNT, Rio de Janeiro

7. Associação Brasileira de Normas Técnicas (2017) NBR 13999: Papel, cartão, pastas celulósicas e madeira - Determinação do resíduo (cinza) após a incineração a $525^{\circ} \mathrm{C}$. ABNT, Rio de Janeiro 
8. Associação Brasileira de Normas Técnicas (2010) NBR 7989: Pastas celulósicas e madeira - Determinação de lignina insolúvel em ácido. ABNT, Rio de Janeiro

9. Benin CC, Watzlawick LF, Hillig E (2017) Physical-mechanical properties of Eucalyptus benthamii wood under effect of planting spacing. Ciênc Florest 27(4):1375-1384. https://doi. org/10.5902/1980509830219

10. Bison Wood-Cement Board Association (1978) Bison technical report

11. Brazilian Tree Industry - BTI (2019) Statistical yearbook. https:// www.iba.org/dados-estatisticos. Accessed 12 Jan 2020

12. Cabral MR, Nakanishi EY, Santos V, Christian G, Santos SF, Fiorelli $J$ (2018) Evaluation of accelerated carbonatation curing in cement-bonded balsa particle board. Mater Struct 51:52. https ://doi.org/10.1617/s11527-018-1179-y

13. Castro VG, Azambuja RR, Parchen CF, Iwakiri S (2019) Alternative vibro-dynamic compression processing of wood-cement composites using Amazonian wood. Acta Amaz 49(1):75-80. https ://doi.org/10.1590/1809-4392201800192

14. Cetris - Boards properties. https://www.cetris.cz/en/advice-andinformation/cetris-board-properties. Accessed 21 Jan 2019

15. Dutra JR, Filho SLM, Christoforo AL, Panzera TH, Scarpa F (2019) Investigation on sustaintable honeycomb sandwich panels containing eucalyptus sawdust, Piassava and cement particles. Thin Walled Struct 143:106191. https://doi.org/10.1016/j. tws.2019.106191

16. European Standard (2002) EN 310. Wood-based boards: determination of modulus of elasticity in bending and of bending strength

17. European Standard (2002) EN 323. Wood based boards-determination of density

18. Guimarães JCO, Cangussú JT, Nunes JS, Lisboa FJN, Guimarães JB Jr (2015) Efficiency of treatment of wood particle eucalyptus hybrid Eucalyptus grandis $x$ Eucalyptus camaldulensis for production of mineral boards. Encicl Biosf 11(21):949-955

19. Hsing TY, Paula NF, Paula RC (2016) Dendrometric and chemical traits and basic density wood of Eucalyptus grandis $x$ Eucalyptus urophylla hybrids. Ciênc Florest 26(1):273-283. https://doi. org/10.5902/1980509821119

20. Iwakiri S, Silva LS, Trianoski R, Bonduelle GM, Rocha VY (2012) Evaluation of potentical use of the wood of Schizolobium amazonicum "Paricá" and Cecropia hololeuca "Embaúba" for wood cement board manufacture. Cerne 18(2):303-308. https://doi. org/10.1590/S0104-77602012000200015

21. Iwakiri S, Trianoski R, Cunha AB, Prata JG, Hara M, Bila NF, Luís RCG, Araújo RD (2015) Technological properties of cementwood panels produced with eucalypt particles. Rev Ciênc Agroveterinárias 14(3):217-223. https://doi.org/10.5965/22381 1711432015217

22. Kallavus U, Järv H, Kalamees T, Kurik L (2017) Assesment of durability of environmentally friendly wood-based panels. Energy Procedia 132(1):207-212. https://doi.org/10.1016/j.egypr 0.2017 .09 .756

23. Li M, Khelifa M, Khennane A, El Ganaoui M (2018) Structural response of cement-bonded wood composite panels as permanent formwork. Compos Struct. https://doi.org/10.1016/j. compstruct.2018.10.079

24. Latorraca JVF, Iwakiri S (2000) Effect of particle treatment of Eucalyptus dunni (Maid), wood:cement ratio and additives on the physical and mechanical properties of wood-cement boards. Cerne 6(1):68-76
25. Latorraca JVF, Teixeira DE, Batista DC (2009) Overlay of cement bonded particleboard of Eucalyptus urophylla for application as flooring panels. For Prod J 59:65-69

26. Macêdo AN, Souza AAC, Pompeu Neto BB (2012) Cementwood particleboards made with waste from the Amazon timber industry. Ambiente Construído 12(2):131-150. https://doi. org/10.1590/S1678-86212012000200009

27. Mendes LM, Loschi FAP, Paula LER, Mendes RF, Guimarães JBG Jr, Mori FA (2011) Utilization potential of wood clones of Eucalyptus urophylla in the production of wood-cement panels. Cerne 17(1):69-75. https://doi.org/10.1590/S0104-776020110001000 08

28. Monteiro S, Martins J, Magalhães FD (2019) Low density wood particleboards bonded with starch foam-study of production process conditions. Materials 12(12):1-14. https://doi. org/10.3390/ma12121975

29. Na B, Wang Z, Wang H, Nanjing XL (2014) Wood-cement compatibility review. Wood Res 59(5):813-826

30. Oliveira CAB, Silva JVF, Bianchi NA, Campos Cl, Oliveira KA, Galdino DS, Bertolini MS, Morais GAG, Souza AJD, Molina JC (2020) Influence of Indian cedar particle pretreatments on cementwood composite properties. BioResources 15(1):1656-1664. https://doi.org/10.15376/biores.15.1.1656-1664

31. Oliveira YMM, Oliveira EB (2017) Plantações florestais: geração de benefícios com baixo impacto ambiental. Embrapa, Brasília

32. Pomarico FA (2017) Potencial de utilização da madeira de Clones de Eucalipto na Produção de Painéis - Cimento. Master dissertation in Forest Science, Federal University of Lavras-UFLA, LavrasMG, Brazil

33. Quiroga A, Marzocchi V, Rintoul I (2016) Influence of wood treatments on mechanical properties of wood-cement composites and of Populus Euroamericana wood fibers. Compos Part B 84(1):25-32. https://doi.org/10.1016/j.compositesb.2015.08.069

34. Rana MN, Islam MN, Nath SK, Das AK, Ashaduzzaman Md, Shams Mdl (2019) Properties of low-density cement-bonded composite panels manufactured from polystyrene and jute stick particles. J Wood Sci 65(53):1-10. https://doi.org/10.1186/s1008 6-019-1831-3

35. Ricciardi P, Cillari G, Miino MC, Collivignarelli MC (2020) Valorization of agro-industry residues in the building and environmental sector: a review. Waste Manag Res 38:1-27. https://doi. org/10.1177/0734242X20904426

36. Sá VA, Mendes LM, Couto AM, Lima NN (2010) Manufacture of cement-bonded particleboard of Australian cedar (Toona ciliata M. Roem var. australis) of different origins and age. Sci For 38(88):558-565

37. Santos UF, Ximenes FS, Luz PB, Seabra Júnior S, Sobrinho SP (2014) Levels of shading on seedling production (Ochroma pyramidale). Biosci J 30(1):129-136

38. Smiderle OJ, Schwengber DR, Oliveira JMF, Jordão SMS, Gomes $\mathrm{HH}$ (2020) Natural availability of seeds of wood species in Cerrado and forest areas of Roraima. Braz J Dev 6(3):9625-9631. https://doi.org/10.34117/bjdv6n3-003

39. Svajlenka J, Kozlovská M, Spisaková M (2017) The benefits of modern method of construction based on wood in the context of sustaintability. Int J Environ Sci Technol 14:1591-1602. https ://doi.org/10.1007/s13762-017-1282-6

Publisher's Note Springer Nature remains neutral with regard to jurisdictional claims in published maps and institutional affiliations. 